\title{
The influence of heat source distribution on the space cooling load oriented to local
} thermal requirements

\author{
Liang, Chao; Melikov, Arsen Krikor; Li, Xianting
}

Published in:

Indoor and Built Environment

Link to article, DOI:

$10.1177 / 1420326 \times 19891632$

Publication date:

2021

Document Version

Peer reviewed version

Link back to DTU Orbit

Citation (APA):

Liang, C., Melikov, A. K., \& Li, X. (2021). The influence of heat source distribution on the space cooling load oriented to local thermal requirements. Indoor and Built Environment, 30(2).

https://doi.org/10.1177/1420326×19891632

\section{General rights}

Copyright and moral rights for the publications made accessible in the public portal are retained by the authors and/or other copyright owners and it is a condition of accessing publications that users recognise and abide by the legal requirements associated with these rights.

- Users may download and print one copy of any publication from the public portal for the purpose of private study or research.

- You may not further distribute the material or use it for any profit-making activity or commercial gain

- You may freely distribute the URL identifying the publication in the public portal

If you believe that this document breaches copyright please contact us providing details, and we will remove access to the work immediately and investigate your claim. 


\title{
The influence of heat source distribution on the space cooling load oriented to local thermal requirements
}

Indoor and Built Environment 0 (0) 1-14

(C) The Author(s) 2019

Article reuse guidelines:

sagepub.com/journals-

permissions

DOI: $10.1177 / 1420326 \times 19891632$ journals.sagepub.com/home/ibe

(S)AGE

\author{
Chao Liang ${ }^{1,2,3} \mathbb{D}$, Arsen Krikor Melikov ${ }^{3}$ and \\ Xianting $\mathbf{L i}^{2}$ (B)
}

\begin{abstract}
Existing studies have shown that the space cooling load oriented to local thermal requirements is significantly influenced by different heat source distributions. However, numerical methods have been mainly used in the analysis based on a fixed airflow field and ignoring the thermal plume. Here, an experiment in a chamber with mixing ventilation was conducted. The heat sources were simulated by metal barrels and an oil-filled radiator, 13 types of heat source distributions were designed and the local cooling load (LCL) was used as the evaluation index. The results show that (1) the LCL is equal to the total amount of heat sources at the steady state in a room with mixing ventilation only if the heat sources are also distributed uniformly; (2) the LCL decreases with a decrease in the intensity of heat sources, achieving a decrease rate of $47.4 \%-70.8 \%$ in the experiment with different intensities; (3) the $\mathrm{LCL}$ is $9.2 \%-22.3 \%$ lower than the total amount of heat sources when these are located near the exhaust diffuser or far away from the target zone; (4) owing to its smaller surface area, the LCL with an oil-filled radiator is $7 \%$ lower than that with five metal barrels.
\end{abstract}

\section{Keywords}

Heat source, Local cooling load, Thermal environment, Mixing ventilation, Temperature distribution, Thermal plume

Accepted: 8 November 2019

\section{Introduction}

The aim of the air-conditioning system in buildings is to enable a comfortable, productive and healthy indoor environment with low cooling load. Owing to the multifold heat transfers in buildings, the space cooling load is affected by many factors, such as the heat sources, air distributions (i.e. ventilation systems) and thermal requirements. ${ }^{1}$ Conventionally, mixing ventilation (MV) is used to design a uniform indoor thermal environment. When the whole room is considered and the indoor air temperature distribution is regarded as uniform, all the heat sources can convert into the space cooling load at the steady state. ${ }^{2}$ In practice, some studies $^{3}$ reported that complete mixing is difficult to achieve, even if $\mathrm{MV}$ is adopted in the room. The indoor air parameters are also distributed non-uniformly, ${ }^{4,5}$ and the air change effectiveness and heat removal efficiency ${ }^{6,7}$ could be less or greater than 1 .

\footnotetext{
${ }^{1}$ College of Water Resources and Civil Engineering, Key Laboratory of Agricultural Engineering in Structure and Environment, China Agricultural University, Ministry of Agriculture and Rural Affairs, Beijing, China

${ }^{2}$ Department of Building Science, School of Architecture, Tsinghua University, Beijing, China

${ }^{3}$ International Centre for Indoor Environment and Energy, Department of Civil Engineering, Technical University of Denmark, Lyngby, Denmark
}

\section{Corresponding author:}

Xianting Li, Department of Building Science, School of Architecture, Tsinghua University, Beijing 100084, China. Email: xtingli@tsinghua.edu.cn 
Recently, with the development of the stratified ventilation methods, e.g. displacement ventilation (DV), underfloor air distribution (UFAD), impinging jet ventilation, wall attached ventilation and protected occupied zone ventilation, researchers realized that the indoor thermal environment is non-uniform and only the occupied zone needs to be guaranteed. ${ }^{8}$ In this case, not all the heat sources can convert into the space cooling load, because only the portion of those entering the occupied zone should be considered. ${ }^{9}$ The different heat source distributions, which means the different intensities, ${ }^{10,11}$ locations, ${ }^{12}$ centralization/decentralization conditions, ${ }^{13,14}$ shapes, ${ }^{11,15}$ ratios of radiation to convection, ${ }^{16}$ heights ${ }^{17}$ or aspect ratios ${ }^{18}$ of the heat sources, have a crucial influence on the indoor air temperature distribution and airflow field. Accordingly, the space cooling load oriented to the occupied zone could be greatly affected by the heat source distribution, which has been reported in the literature. Park and Holland ${ }^{19}$ found that the space cooling load oriented to the occupied zone decreased significantly as the heat source height rose in a room with DV, with the greatest decrease rate, $80 \%$, when the heat source was located at $2 \mathrm{~m}$ high. Zheng et al. ${ }^{20}$ conducted an experiment in a chamber with DV, and the results showed that the temperature stratification could be broken to increase the space cooling load when a hot window was installed. Cheng et al. ${ }^{21}$ found that the space cooling load is associated with the types of heat sources (wall, window, computer, occupant, lamp, etc.) in an office, classroom and airport terminal. The distance between the heat sources and return/exhaust grills is also important to the space cooling load. ${ }^{22}$ Specially, when the heat sources (e.g. the lights) are combined with the exhaust grills, the heat sources have little influence on the occupied zone, and therefore it could be reduced as much as $47.7 \%$, as stated in Ahmed et al. ${ }^{23}$ Furthermore, some calculation methods were proposed to quickly obtain the relationship between the heat sources and space cooling load for the stratified ventilation methods. Loudermilk ${ }^{24}$ recommended that effective heat gain factors be applied in calculating the space cooling load for the UFAD, and Chen and Glicksman ${ }^{25}$ built a prediction model for DV with the effective cooling load factors to calculate it. These factors reflect the weighting coefficients for the contribution of the heat sources to the occupied zone, which can be obtained by case-by-case computational fluid dynamics simulations or referred to the empirical values directly.

Generally, for indoor environment creation in residential, ${ }^{26,27}$ commercial $^{28,29}$ and industrial ${ }^{30,31}$ buildings and vehicle compartments, ${ }^{32,33}$ only a local zone needs to be protected from the thermal discomfort and air pollution, which is quite smaller than the occupied zone or whole room. In view of this, researchers have proposed the personalized ventilation, ${ }^{34,35}$ local exhaust ventilation ${ }^{36,37}$ and some other novel systems $s^{38-41}$ to create a local or micro thermal environment for satisfying the local requirements. Because only the air temperature of the local zone is maintained in the indoor environment, the influence of heat source distribution on the space cooling load oriented to the local zone will be very different, not only for the personalized ventilation and local exhaust ventilation, but also for the stratified ventilation and traditional MV. Subsequently, Liang et al. ${ }^{42,43}$ defined a new index, i.e. the local cooling load (LCL), to evaluate it quantitatively. Several numerical cases were designed to demonstrate that the LCL is usually not equal to the total amount of heat sources. With the help of the LCL, the supply air parameters could be determined for designing the air terminals in non-uniform indoor environments oriented to local zone, which have been applied in the design of the air curtain system ${ }^{44}$ and multi-mode ventilation system. ${ }^{45}$

However, the existing studies of the relationship between heat sources and LCL were mainly based on the numerical method, and there is limited work with the experimental method. Moreover, the main results were obtained on the premise of a fixed airflow field and constant heat gain from the envelope. As mentioned above, both of them are greatly influenced by the non-uniform temperature and thermal plume, and therefore this indicates that there are some deviations in this premise. In addition, the types of heat source distributions discussed in the previous studies were quite limited, and they are not sufficient to analyse their influence on the LCL. Actually, the heat source distributions in buildings are diverse and changeable (e.g. lights on/off, occupant movement, sunlight changes with time and climate), ${ }^{46,47}$ and they could have different heat gain levels. ${ }^{48,49}$ Therefore, the aim of this study is to further analyse the influence of different heat source distributions on the space cooling load oriented to local thermal requirements by using the experimental method. The experiment was conducted in a test chamber with the size of $4.12 \mathrm{~m}(\mathrm{~L}) \times 4.20 \mathrm{~m}(\mathrm{~W}) \times 2.89 \mathrm{~m}(\mathrm{H})$ at the Technical University of Denmark, and the heat sources were simulated by metal barrels with relatively low heat dissipation and an oil-filled radiator with relatively high heat dissipation. MV was installed in the chamber, but only the average temperature in a local zone with size of $1.37 \mathrm{~m}(\mathrm{~L}) \times 1.4 \mathrm{~m}(\mathrm{~W}) \times 1.4 \mathrm{~m}(\mathrm{H})$ needed to be maintained during the measurement. The LCL was used as the evaluation index to calculate the space cooling load oriented to local thermal requirements. To consider as many as possible different heat source distributions, 13 experimental cases with different intensities, locations, shapes and degrees of concentration of 
the heat sources were designed. These 13 cases were divided into two series, i.e. the low-load $(420 \mathrm{~W})$ and high-load $(840 \mathrm{~W})$ series, for considering the usual (average) and design (peak) cooling load, respectively. The experimental results in this study will be beneficial for designing an efficient indoor thermal environment oriented to local requirements, optimizing the supply air parameters ${ }^{50}$ and operating the air-conditioning system with low energy. ${ }^{51}$

\section{Methodology}

\section{Experimental facility}

Test chamber and heat sources. The layout of the full-scale test chamber with the size of $4.12 \mathrm{~m}$ $(\mathrm{L}) \times 4.20 \mathrm{~m}(\mathrm{~W}) \times 2.89 \mathrm{~m}(\mathrm{H})$ is shown in Figure 1 (a). The test chamber was situated in a large laboratory hall, and therefore a fairly stable ambient environment could be kept. The envelope was mainly made of the polyurethane (PU) sandwich panel and wood, and the heat transfer coefficients of them could refer to the previous study. ${ }^{42}$ However, the insulation performance was poor because of the long time of use (since 2001), and therefore the non-uniform heat transfer from the envelope was considered when checking the heat balance in the chamber and analysing the experimental results. Two fluorescent lamps were suspended at a height of $2.45 \mathrm{~m}$, each of which had a heat dissipation of $40 \mathrm{~W}$. A supply diffuser with two slots (Halton SLN472 , with the maximum air flow rate of $0.047 \mathrm{~m}^{3} / \mathrm{s}$ ) and two exhaust diffusers were placed on the ceiling. The space of the chamber was divided uniformly into nine local zones and only a local zone, i.e. Zone D with size of $1.37 \mathrm{~m}(\mathrm{~L}) \times 1.4 \mathrm{~m}(\mathrm{~W}) \times 1.4 \mathrm{~m}(\mathrm{H})$, was guaranteed during the measurement, as shown in Figure 1(b).

In this experiment, several metal barrels with the heating wire coiled inside and an oil-filled radiator (Ufesa RU-7/15) which have different surface areas (including different shapes and numbers) were used to simulate the heat sources (except the lighting and envelope), as shown in Figure 2. The heat dissipations of the heat sources could be set by a voltage transformer and measured by a power meter. The metal barrel was nearly a cylinder with the height of $0.785 \mathrm{~m}$ and the diameter of $0.4 \mathrm{~m}$, and its surface area was $1.073 \mathrm{~m}^{2}$. The size of the oil-filled radiator was $0.39 \mathrm{~m}(\mathrm{~L}) \times 0.16 \mathrm{~m}(\mathrm{~W}) \times 0.6 \mathrm{~m}$ $(\mathrm{H})$, and its surface area was $1.766 \mathrm{~m}^{2}$. Owing to

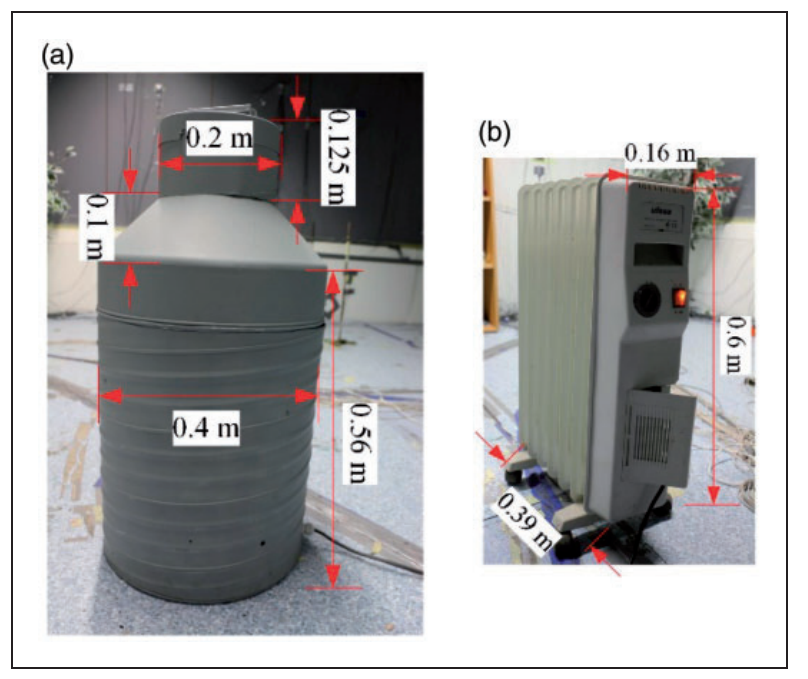

Figure 2. Heat sources in the experiment. (a) Metal barrel and (b) oil-filled radiator.

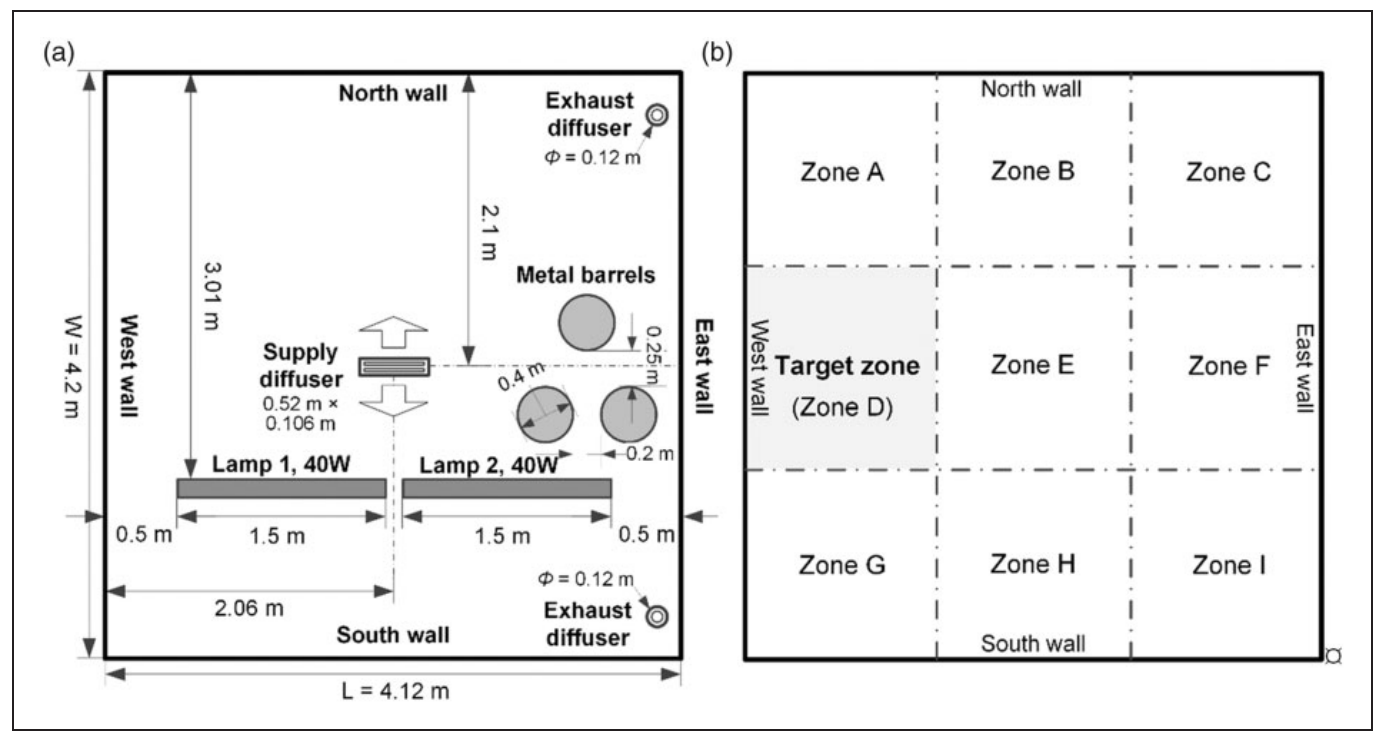

Figure 1. (a) Test chamber layout and (b) target zone. 
the different surface areas, the heat dissipations per unit area of the metal barrel and oil-filled radiator were different to represent the heat source with relatively low intensity (e.g. the occupant, laptop, monitor and printer) ${ }^{52}$ and heat source with relatively high intensity (e.g. the strong solar radiation, large screen, oven and high-power electrical appliance), ${ }^{53}$ respectively.

Air-conditioning system. The principle of the airconditioning system in this experiment is shown in Figure 3.

A centralized chiller was installed to ensure the indoor environment of the whole building where the test chamber was located. To control the test chamber independently, an additional air-water heat exchanger and control system were equipped. First, the outdoor fresh air was cooled by the centralized chiller and controlled at a fixed temperature, which was set to $26^{\circ} \mathrm{C}$ in this experiment. Then, it was cooled by the air-water heat exchanger and supplied into the chamber through the supply diffuser. Finally, the air was mixed and discharged directly through the exhaust diffusers to the ambient environment in the laboratory hall.

Measurement sensors. Four PT100 temperature sensors (accuracy of $\pm 0.15^{\circ} \mathrm{C}$ ) were placed at the height of $0.7 \mathrm{~m}$ in Zone D to monitor the average air temperature of the target zone, as shown in Figure 4(a). The indoor air parameter distributions were measured by moving a steel pole with several PT100 and AirDistSys5000 velocity sensors (accuracy of $\pm 0.02 \mathrm{~m} / \mathrm{s}$ ), as shown in Figure 4(b). The moving positions of the steel pole were the centres of the local zones (except Zone D). According to ISO 7726 standard, ${ }^{54}$ the sensors were placed at heights of 0.1 , $0.3,0.6,1.4,1.7,2.1$ and $2.6 \mathrm{~m}$, respectively. Every time the pole was moved by the experimenter, the chamber needed 30-40 min to reach stability again.

Additionally, an FCO510 micromanometer (accuracy of $\pm 0.5 \mathrm{~Pa}$ ), TA-SCOPE HP balancing instrument (accuracy of $\pm 0.2 \mathrm{kPa}$ ) and PT100 were installed to monitor and adjust the supply and exhaust air volumes, cooling water flow rate and cooling water, supply air, exhaust air and ambient air temperatures for ensuring the required experimental conditions, as shown in Figure 3. During the measurement, the ambient environment was stable at $22.5^{\circ} \mathrm{C}$.

\section{Experimental cases}

According to the EN $15251^{55}$ and ISO $7730^{56}$ standards, the low-load (or usual-load) with $420 \mathrm{~W}$ and highload (or design-load) with $840 \mathrm{~W}$ were considered. Thirteen types of heat source distributions, which include different intensities, locations, shapes and degrees of concentration of the heat sources, were designed in this experiment, as shown in Figure 5.

As shown in Figure 5(a) to (i), three metal barrels with heat dissipation of $3 \times 140 \mathrm{~W}$ were localized in the different local zones. An oil-filled radiator and five metal barrels with the same heat dissipation of $840 \mathrm{~W}$ were localized in Zone E in Figure 5(j) and (k), whereas the five metal barrels were distributed in multiple local zones in Figure 5(l) and (m). The two lamps in the experimental chamber were dominated by radiative

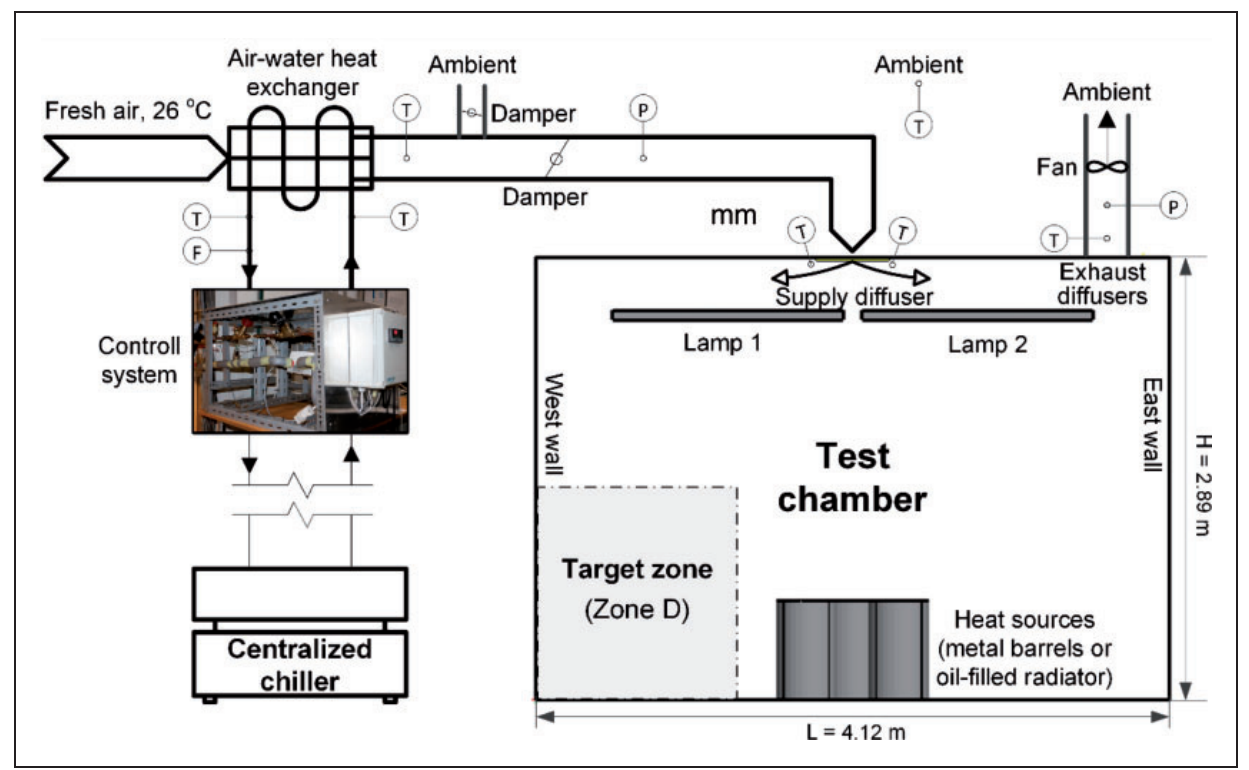

Figure 3. Principle of the air-conditioning system in the experiment.

F: water flow rate sensor; P: air pressure sensor; T: air/water temperature sensor. 


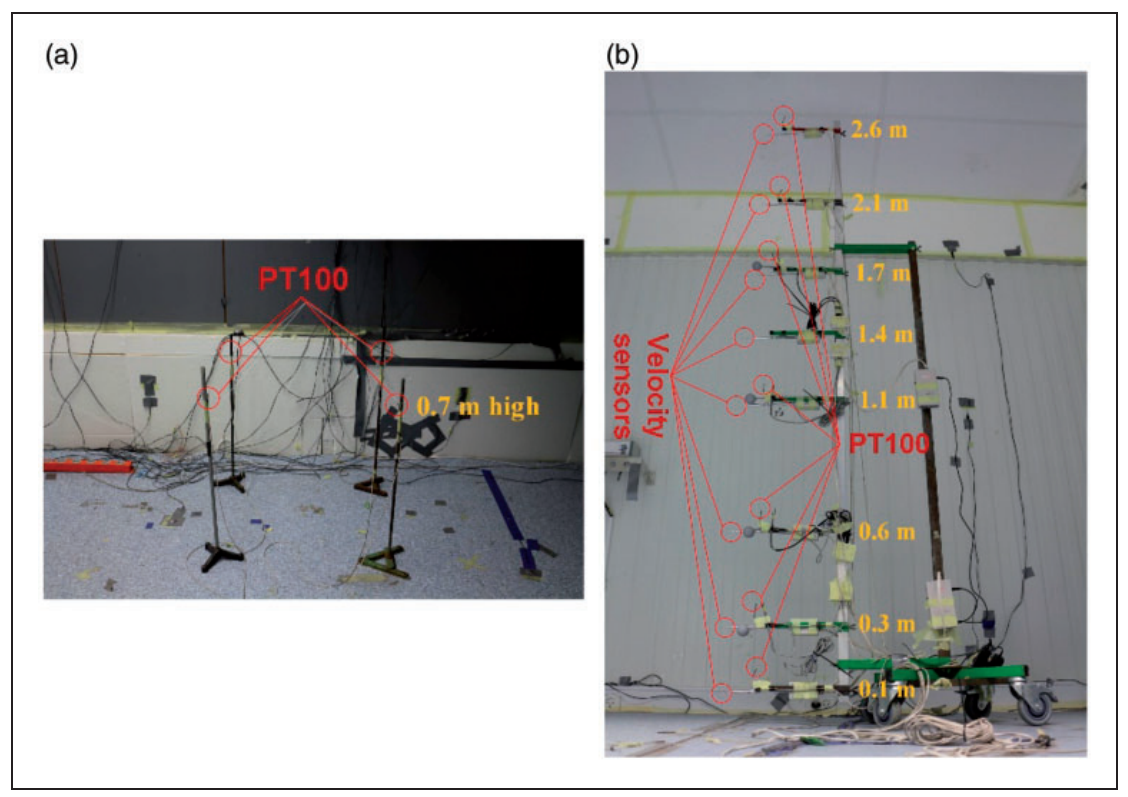

Figure 4. Indoor air temperature and velocity sensors. (a) Four PT100 in target zone and (b) steel pole with sensors.

heat transfer, which eventually distributed to the inner surfaces (mainly the envelope) relatively uniformly, and therefore their influence on the non-uniform distribution of heat sources was ignored in this experiment.

Based on the different heat source distributions in Figure 5, 13 experimental cases were designed, as shown in Table 1.

In Table 1, Cases L-1 to L-9 are the low-load cases with $420 \mathrm{~W}$, and Cases $\mathrm{H}-1$ to $\mathrm{H}-4$ are the high-load cases with $840 \mathrm{~W}$. The supply air volumes in the lowload and high-load cases were fixed at $0.0235 \mathrm{~m}^{3} / \mathrm{s}$ and $0.047 \mathrm{~m}^{3} / \mathrm{s}$, respectively. The set temperatures of the target zone (i.e. Zone D) in the low-load and highload cases were $26^{\circ} \mathrm{C}^{47}$ and $29^{\circ} \mathrm{C},{ }^{57,58}$ respectively. By comparing the low-load and high-load cases, the influence of the intensity of heat sources on the space cooling load oriented to local thermal requirements was analysed; by comparing Cases L-1 to L-9, the influence of the location of heat sources was analysed; by comparing Cases $\mathrm{H}-1$ and $\mathrm{H}-2$, the influence of the shape of heat sources was analysed and by comparing Cases $\mathrm{H}$ 2, H-3 and H-4, the difference between the localized and distributed heat sources was analysed.

\section{Experimental procedures}

First, the exhaust fan was adjusted to attain an exhaust air volume flow rate equal to the supply air volume flow rate, and therefore an airflow balance was obtained in the chamber. Second, by keeping the supply air volume at $0.0235 \mathrm{~m}^{3} / \mathrm{s}$ for the low-load cases (or $0.047 \mathrm{~m}^{3} / \mathrm{s}$ for the high-load cases), the supply air temperature was adjusted multiple times to attain the average temperature in Zone D at $26^{\circ} \mathrm{C}$ for the low-load cases (or $29^{\circ} \mathrm{C}$ for the high-load cases). Third, when the indoor air parameters were basically unchanged, a steady condition was achieved. Then, the indoor air parameter distributions were measured by moving the steel pole with sensors. Finally, by changing the heat source distribution and repeating the steps above, the other experimental cases in Table 1 could be measured.

\section{Evaluation index}

The LCL was used in this study to evaluate the space cooling load oriented to local thermal requirements. The LCL means the cooling capacity provided by the air terminals for only maintaining the local zone, which is defined as equation $(1)^{42,43}$

$$
Q_{\text {local }}=c_{p} m_{s}\left(T_{\text {local_set }}-T_{s}\right)
$$

where $Q_{\text {local }}$ is the $\mathrm{LCL}, \mathrm{W} ; c_{p}$ is the specific heat capacity of air, $\mathrm{J} /(\mathrm{kg} \cdot \mathrm{K}) ; m_{s}$ is the supply air mass flow rate, $\mathrm{kg} / \mathrm{s} ; T_{\text {local_set }}$ is the set temperature in the local zone, ${ }^{\circ} \mathrm{C}$ and $T_{s}$ is the supply air temperature, ${ }^{\circ} \mathrm{C}$.

In the conventional uniform indoor environment, the space cooling load is equal to the total heat gains (i.e. the total amount of heat sources) at the steady state, as shown in equation (2).

$$
Q_{\text {space }}=c_{p} m_{s}\left(T_{\text {set }}-T_{s}\right)=c_{p} m_{s}\left(T_{e}-T_{s}\right)=q_{\text {gain }}
$$

where $Q_{\text {space }}$ is the space cooling load in uniform indoor environments, $\mathrm{W} ; T_{\text {set }}$ is the set temperature in the whole room, ${ }^{\circ} \mathrm{C} ; T_{e}$ is the exhaust air temperature, ${ }^{\circ} \mathrm{C}$ and $q_{\text {gain }}$ is the total heat gains in the room, $\mathrm{W}$. 


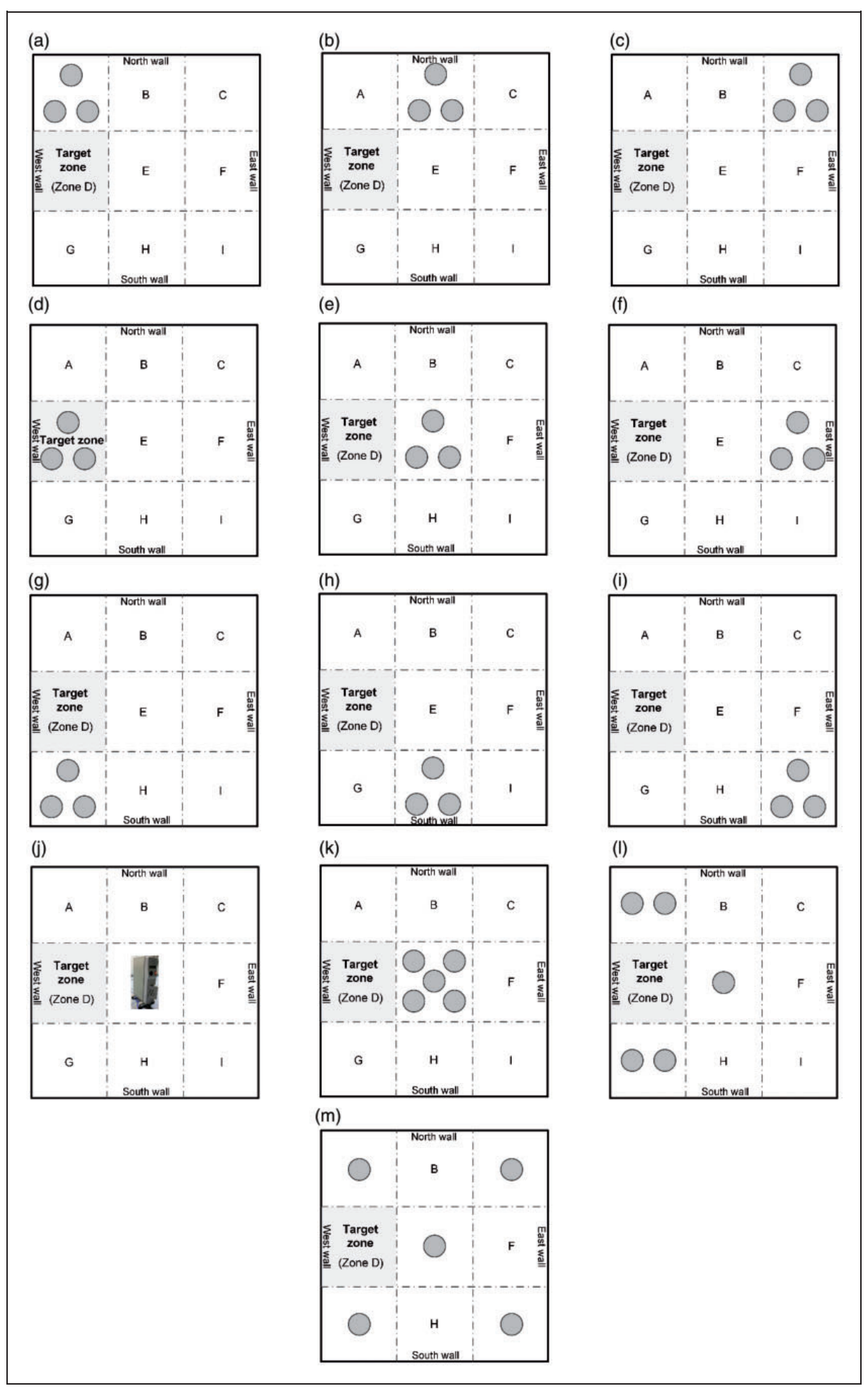

Figure 5. Thirteen types of heat source distributions. (a) Three metal barrels with $3 \times 140 \mathrm{~W}$ are localized in Zone A, (b) three metal barrels with $3 \times 140 \mathrm{~W}$ are localized in Zone B, (c) three metal barrels with $3 \times 140 \mathrm{~W}$ are localized in Zone C, (d) three metal barrels with $3 \times 140 \mathrm{~W}$ are localized in Zone D, (e) three metal barrels with $3 \times 140 \mathrm{~W}$ are localized in Zone E, (f) three metal barrels with $3 \times 140 \mathrm{~W}$ are localized in Zone F, (g) three metal barrels with $3 \times 140 \mathrm{~W}$ are localized in Zone G, (h) three metal barrels with $3 \times 140 \mathrm{~W}$ are localized in Zone $\mathrm{H}$, (i) three metal barrels with $3 \times 140 \mathrm{~W}$ are localized in Zone I, (j) one oil-filled radiator with $840 \mathrm{~W}$ is localized in Zone E, (k) five metal barrels with $5 \times 168 \mathrm{~W}$ are localized in Zone $\mathrm{E}$, (1) five metal barrels with $5 \times 168 \mathrm{~W}$ are distributed in Zones $\mathrm{A}, \mathrm{E}$ and $\mathrm{G}$ and $(\mathrm{m})$ five metal barrels with $5 \times 168 \mathrm{~W}$ are distributed uniformly in Zones A, C, E, G and I. 
Table 1. Experimental cases.

\begin{tabular}{|c|c|c|c|c|c|}
\hline Case no. & $\begin{array}{l}\text { Intensity of heat } \\
\text { sources }\end{array}$ & $\begin{array}{l}\text { Type of heat } \\
\text { sources }\end{array}$ & $\begin{array}{l}\text { Location of } \\
\text { heat sources }\end{array}$ & Supply air volume & Target zone \\
\hline L-1 & \multirow[t]{9}{*}{$420 \mathrm{~W}$ in total } & \multirow[t]{9}{*}{ Three metal barrels } & Zone A & \multirow{9}{*}{$\begin{array}{l}\text { Fixed at } \\
\quad 0.0235 \mathrm{~m}^{3} / \mathrm{s}\end{array}$} & \multirow{9}{*}{$\begin{array}{l}\text { Zone D, maintained } \\
\text { at } 26^{\circ} \mathrm{C}\end{array}$} \\
\hline $\mathrm{L}-2$ & & & Zone B & & \\
\hline L-3 & & & Zone C & & \\
\hline $\mathrm{L}-4$ & & & Zone D & & \\
\hline $\mathrm{L}-5$ & & & Zone E & & \\
\hline L-6 & & & Zone F & & \\
\hline $\mathrm{L}-7$ & & & Zone G & & \\
\hline L-8 & & & Zone $\mathrm{H}$ & & \\
\hline L-9 & & & Zone I & & \\
\hline H-1 & \multirow[t]{4}{*}{$840 \mathrm{~W}$ in total } & An oil-filled radiator & Zone E & \multirow{4}{*}{$\begin{array}{l}\text { Fixed at } \\
\quad 0.047 \mathrm{~m}^{3} / \mathrm{s}\end{array}$} & \multirow{4}{*}{$\begin{array}{l}\text { Zone } \mathrm{D} \text {, maintained } \\
\text { at } 29^{\circ} \mathrm{C}\end{array}$} \\
\hline $\mathrm{H}-2$ & & Five metal barrels & Zone E & & \\
\hline $\mathrm{H}-3$ & & & Zones $\mathrm{A}, \mathrm{E}$ and $\mathrm{G}$ & & \\
\hline H-4 & & & Zones A, C, E, G and I & & \\
\hline
\end{tabular}

Table 2. Final supply and exhaust air temperatures in 13 experimental cases.

\begin{tabular}{|c|c|c|c|c|c|c|c|c|c|c|c|c|c|}
\hline & $\begin{array}{l}\text { Case } \\
\text { L-1 }\end{array}$ & $\begin{array}{l}\text { Case } \\
\text { L-2 }\end{array}$ & $\begin{array}{l}\text { Case } \\
\text { L-3 }\end{array}$ & $\begin{array}{l}\text { Case } \\
\text { L-4 }\end{array}$ & $\begin{array}{l}\text { Case } \\
\text { L-5 }\end{array}$ & $\begin{array}{l}\text { Case } \\
\text { L-6 }\end{array}$ & $\begin{array}{l}\text { Case } \\
\text { L-7 }\end{array}$ & $\begin{array}{l}\text { Case } \\
\text { L-8 }\end{array}$ & $\begin{array}{l}\text { Case } \\
\text { L-9 }\end{array}$ & $\begin{array}{l}\text { Case } \\
\text { H-1 }\end{array}$ & $\begin{array}{l}\text { Case } \\
\mathrm{H}-2\end{array}$ & $\begin{array}{l}\text { Case } \\
\text { H-3 }\end{array}$ & $\begin{array}{l}\text { Case } \\
\mathrm{H}-4\end{array}$ \\
\hline $\begin{array}{l}\text { Supply air } \\
\text { temperature }\left({ }^{\circ} \mathrm{C}\right)\end{array}$ & 16.0 & 17.3 & 18.3 & 14.2 & 15.0 & 17.0 & 15.8 & 17.2 & 18.1 & 16.6 & 15.8 & 16.7 & 17.6 \\
\hline $\begin{array}{l}\text { Exhaust air } \\
\text { temperature }\left({ }^{\circ} \mathrm{C}\right)\end{array}$ & 26.0 & 26.2 & 26.9 & 24.7 & 25.4 & 26.5 & 26.0 & 26.2 & 26.9 & 27.9 & 27.1 & 27.8 & 29.0 \\
\hline
\end{tabular}

Table 3. Indoor air temperature distribution in Case L-5 (unit is ${ }^{\circ} \mathrm{C}$ ).

\begin{tabular}{lllllllll}
\hline & Zone A & Zone B & Zone C & Zone E & Zone F & Zone G & Zone H & Zone I \\
\hline $\mathrm{H}=0.1 \mathrm{~m}$ & 25.9 & 25.8 & 25.5 & 28.0 & 25.5 & 25.8 & 25.6 & 25.5 \\
$\mathrm{H}=0.3 \mathrm{~m}$ & 25.9 & 25.9 & 25.5 & 28.2 & 25.6 & 25.8 & 25.8 & 25.5 \\
$\mathrm{H}=0.6 \mathrm{~m}$ & 25.9 & 25.9 & 25.7 & 27.6 & 25.7 & 25.9 & 25.9 & 25.6 \\
$\mathrm{H}=1.1 \mathrm{~m}$ & 25.9 & 25.9 & 25.7 & 26.0 & 25.7 & 25.9 & 26.0 & 25.6 \\
$\mathrm{H}=1.7 \mathrm{~m}$ & 25.9 & 25.9 & 25.8 & 25.7 & 25.7 & 26.1 & 25.9 & 25.7 \\
$\mathrm{H}=2.1 \mathrm{~m}$ & 25.9 & 25.9 & 25.8 & 25.7 & 25.8 & 26.1 & 25.9 & 25.7 \\
$\mathrm{H}=2.6 \mathrm{~m}$ & 26.0 & 24.4 & 25.6 & 25.7 & 25.8 & 26.2 & 24.5 & 25.5 \\
\hline
\end{tabular}

However, in the non-uniform indoor environment oriented to local zone, $T_{\text {local_set }}$ is usually not equal to $T_{e}$. Therefore, the LCL can be less or greater than the total heat gains, according to equation (1). The LCL actually reflects the influence of the heat sources on the local zone under a specific airflow pattern at the steady state.

\section{Result and discussion}

\section{Indoor air temperature distribution}

When the average temperature in the target zone reached the set value, the final supply and exhaust air temperatures in each experimental case were obtained, as listed in Table 2.
From Table 2, the supply and exhaust air temperatures vary with the different heat source distributions. At the same time, the air temperature in each local zone (except Zone D) was measured. Owing to space constraints, only Case L-5 with three metal barrels in Zone $\mathrm{E}$ and Case $\mathrm{H}-2$ with five metal barrels in Zone $\mathrm{E}$ are displayed as examples, as presented in Tables 3 and 4 .

As can be observed in Tables 3 and 4, the indoor air temperature was still distributed non-uniformly, although this test chamber was equipped with MV. The air temperature in Zone $\mathrm{E}$ was relatively high because the metal barrels were localized in that zone. The air temperatures in Zones $\mathrm{B}$ and $\mathrm{H}$ at a height of $2.6 \mathrm{~m}$ were relatively low $\left(24.4^{\circ} \mathrm{C}\right.$ and $24.5^{\circ} \mathrm{C}$ in Case L-5, respectively; $27.9^{\circ} \mathrm{C}$ and $27.8^{\circ} \mathrm{C}$ in Case $\mathrm{H}-2$, 
Table 4. Indoor air temperature distribution in Case $\mathrm{H}-2$ (unit is ${ }^{\circ} \mathrm{C}$ ).

\begin{tabular}{|c|c|c|c|c|c|c|c|c|}
\hline & Zone A & Zone B & Zone C & Zone E & Zone $\mathrm{F}$ & Zone $\mathrm{G}$ & Zone $\mathrm{H}$ & Zone I \\
\hline $\mathrm{H}=0.1 \mathrm{~m}$ & 28.9 & 28.9 & 28.2 & 30.0 & 28.3 & 28.9 & 28.8 & 28.3 \\
\hline $\mathrm{H}=0.3 \mathrm{~m}$ & 28.9 & 29.0 & 28.3 & 29.8 & 28.3 & 28.9 & 28.9 & 28.3 \\
\hline $\mathrm{H}=0.6 \mathrm{~m}$ & 28.9 & 28.9 & 28.3 & 29.5 & 28.3 & 28.9 & 28.8 & 28.2 \\
\hline $\mathrm{H}=1.1 \mathrm{~m}$ & 28.9 & 28.8 & 28.4 & 28.6 & 28.5 & 28.9 & 28.8 & 28.3 \\
\hline $\mathrm{H}=1.7 \mathrm{~m}$ & 29.0 & 28.8 & 28.5 & 28.5 & 28.5 & 29.0 & 28.7 & 28.5 \\
\hline $\mathrm{H}=2.1 \mathrm{~m}$ & 29.1 & 28.7 & 28.5 & 28.4 & 28.4 & 29.0 & 28.7 & 28.5 \\
\hline $\mathrm{H}=2.6 \mathrm{~m}$ & 29.2 & 27.9 & 28.7 & 28.4 & 28.5 & 29.3 & 27.8 & 28.8 \\
\hline
\end{tabular}

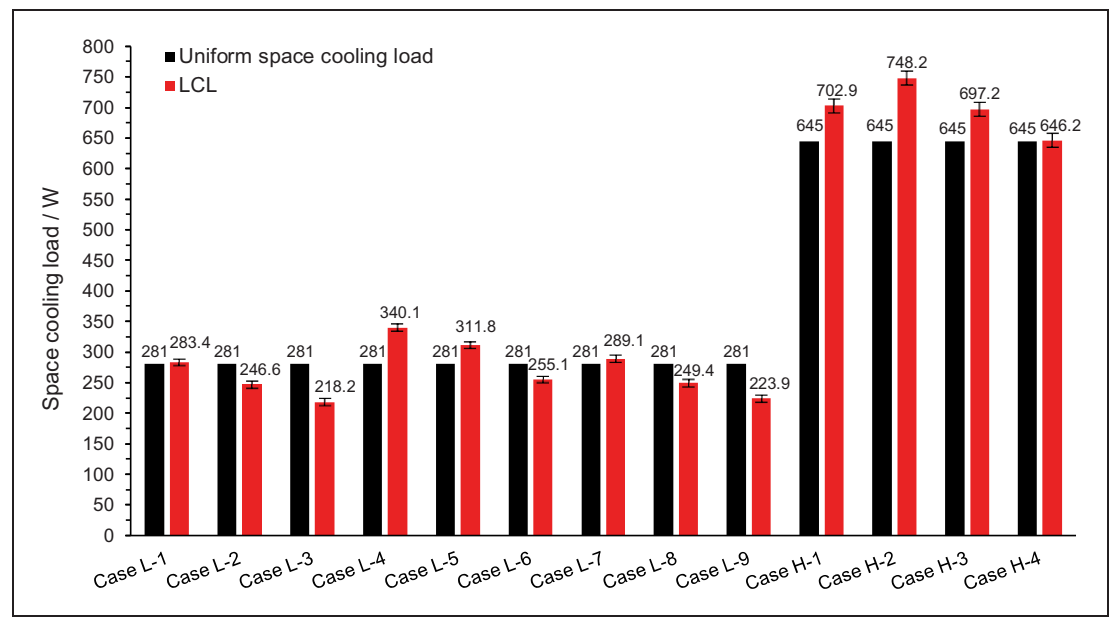

Figure 6. Influence of the intensity of heat sources on LCL. LCL: local cooling load.

respectively), because the two zones were within the region of influence of the supply air jet. Additionally, owing to the symmetrical diffusers and heat sources, the horizontal air temperature distributions were almost symmetrical in the south-north direction.

\section{Influence of the intensity of localized heat sources on the $L C L$}

According to equation (1), the LCL in 13 experimental cases was calculated with the supply air temperatures in Table 2. The results are shown in Figure 6.

The uniform space cooling load in Figure 6 is the space cooling load in the ideal uniform $\left(26^{\circ} \mathrm{C}\right.$ or $\left.29^{\circ} \mathrm{C}\right)$ indoor environment, which equals to the total heat gain (including the heat gain from the envelope) and was calculated based on equation (2). They were $281 \mathrm{~W}$ and $645 \mathrm{~W}$ for the low-load and high-load cases, respectively, and were regarded as the reference values for comparison.

Obviously, the LCL decreases with the decrease in the intensity of heat sources, as shown in Figure 6. The LCL ranges, respectively, from $646.2 \mathrm{~W} \pm 11.2 \mathrm{~W}$ to $748.2 \mathrm{~W} \pm 11.2 \mathrm{~W}$ in Cases $\mathrm{H}-1$ to $\mathrm{H}-4$ with high intensity, but ranges from $218.2 \mathrm{~W} \pm 5.6 \mathrm{~W}$ to
$340.1 \mathrm{~W} \pm 5.6 \mathrm{~W}$ in Cases L-1 to L-9 with low intensity, indicating a decrease rate of $47.4 \%-70.8 \%$. Additionally, the LCL was $16.0 \%$ higher than the uniform space cooling load in Case $\mathrm{H}-2$, but only $10.9 \%$ in Case L-5. These two cases have the same location and shape of heat sources but different intensity. Owing to the higher intensity of the heat sources, the Archimedes number (which reflects the ratio of buoyancy to inertia forces) would be greater and the thermal plume would be stronger, as reported in the literature. ${ }^{10,11}$ Therefore, in comparison to the forced convection (i.e. the supply air), the natural convection (i.e. the thermal plume of localized heat sources) would be considerable in the high-load Case $\mathrm{H}-2$, resulting in a greater influence to the target zone and higher LCL.

\section{Influence of the location of localized heat sources on the $L C L$}

By comparing the LCL in Cases L-1 to L-9, the influence of heat source location on the LCL was analysed, and the results are shown in Figure 7.

As can be seen in Figure 7, the heat source location has a great influence on the LCL, with the maximum at 


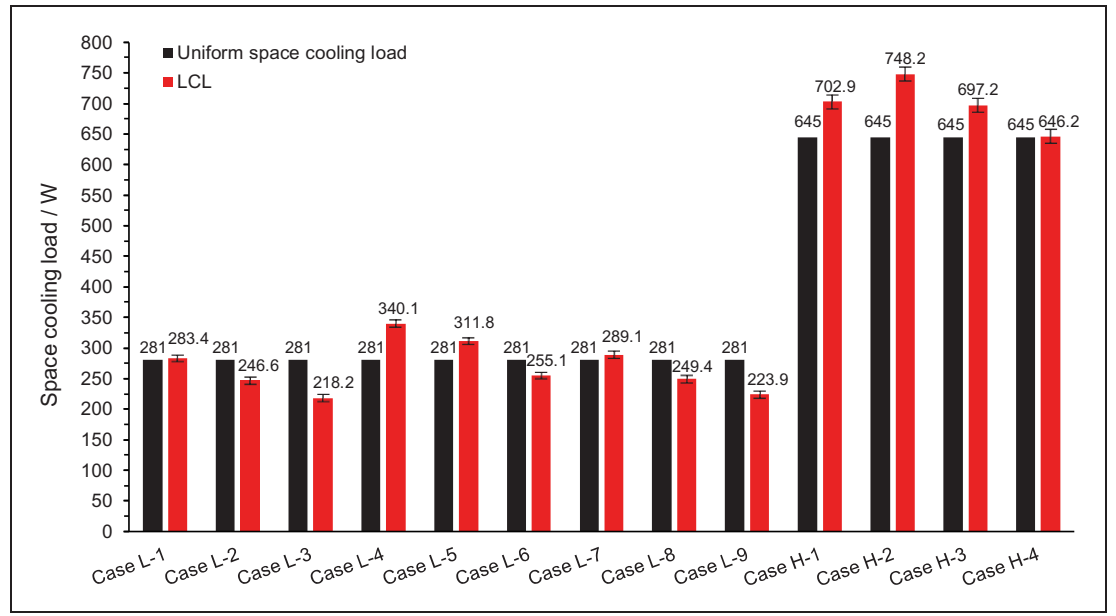

Figure 7. Influence of the location of heat sources on LCL. LCL: local cooling load.

$340.1 \mathrm{~W} \pm 5.6 \mathrm{~W}$ and minimum at $218.2 \mathrm{~W} \pm 5.6 \mathrm{~W}$. The LCL in Cases L-1, L-4, L-5 and L-7 are $0.9 \%$, $21.0 \%, 10.9 \%$ and $2.9 \%$ greater than the uniform space cooling load, respectively. This is because the metal barrels (i.e. the localized heat sources) in these four cases are relatively close to Zone D (i.e. the target zone), which leads to a greater influence on the average temperature of the target zone. Specially, in Case L-4, the localized heat sources are all located in the target zone, and therefore the supply air temperature is the lowest at $14.2^{\circ} \mathrm{C}$ and the LCL is the highest at $340.1 \mathrm{~W}$. On the contrary, because the localized heat sources are far away from the target zone or close to the exhaust diffuser, the LCL in Cases L-2, L-3, L-6, L-8 and L-9 are $12.3 \%, 22.3 \%, 9.2 \%, 11.2 \%$ and $20.3 \%$ less than the uniform space cooling load, respectively. Specially, in Cases L-3 and L-9, the localized heat sources are furthest away from the target zone and just below the exhaust diffuser. This makes it easier to remove the heat directly by the exhaust air and leads to the smallest influence on the target zone. Therefore, the supply air temperature is the highest $\left(18.3^{\circ} \mathrm{C}\right.$ and $18.1^{\circ} \mathrm{C}$, respectively) and the LCL is the lowest $(218.2 \mathrm{~W}$ and $223.9 \mathrm{~W}$, respectively).

Although the average air temperature of the target zone is the same, $26^{\circ} \mathrm{C}$, in Cases L- 1 to L-9, the air temperatures in the other zones are different. Owing to space constraints, only the horizontal temperature distributions at a height of $0.6 \mathrm{~m}$ (usually represents the average height of a sitting person ${ }^{47,57}$ ) are shown in Figure 8.

According to the results in Figure 8, the air temperature was mostly lower than $26^{\circ} \mathrm{C}$ in Cases L-1, L-4, L-5 and L-7. This indicates that the heat loss from the envelope was lower, and more cooling capacity was supplied into the room in comparison with that for creating an ideal uniform $\left(26^{\circ} \mathrm{C}\right)$ indoor environment. Therefore, the LCL was greater than the uniform space cooling load (shown in Figure 7). However, the air temperature was mostly higher than $26^{\circ} \mathrm{C}$ in Cases L-2, L-3, L-6, L-8 and L-9, which indicates that the heat loss from the envelope was greater and less cooling capacity was supplied into the room, and therefore lower LCLs were obtained (shown in Figure 7).

\section{Influence of the shape of localized heat sources on the $L C L$}

The influence of heat source shape on the LCL was analysed by comparing Cases H-1 and H-2. The experimental results are shown in Figure 9.

As can be observed in Figure 9, the LCL in Case H-1 with the oil-filled radiator was $7 \%(45.3 \mathrm{~W})$ lower than that in Case $\mathrm{H}-2$ with five metal barrels. This is because the shapes of the oil-filled radiator and five metal barrels are different, although they are both located in Zone $\mathrm{E}$ and their heat dissipations are both $840 \mathrm{~W}$. The surface area of the oil-filled radiator $\left(1.766 \mathrm{~m}^{2}\right)$ is much smaller than that of the five metal barrels $\left(1.073 \mathrm{~m}^{2} \times 5\right)$, so the surface temperature is much higher. Because the radiation heat transfer is the fourth power of the temperature difference, but only the first power of the area, more heat is dissipated by radiation for the oil-filed radiator. Then, the radiation heat is distributed to the inner surfaces (mainly the envelope) based on the angular coefficient, and it finally warms the surrounding air through convection. ${ }^{11,19}$ 


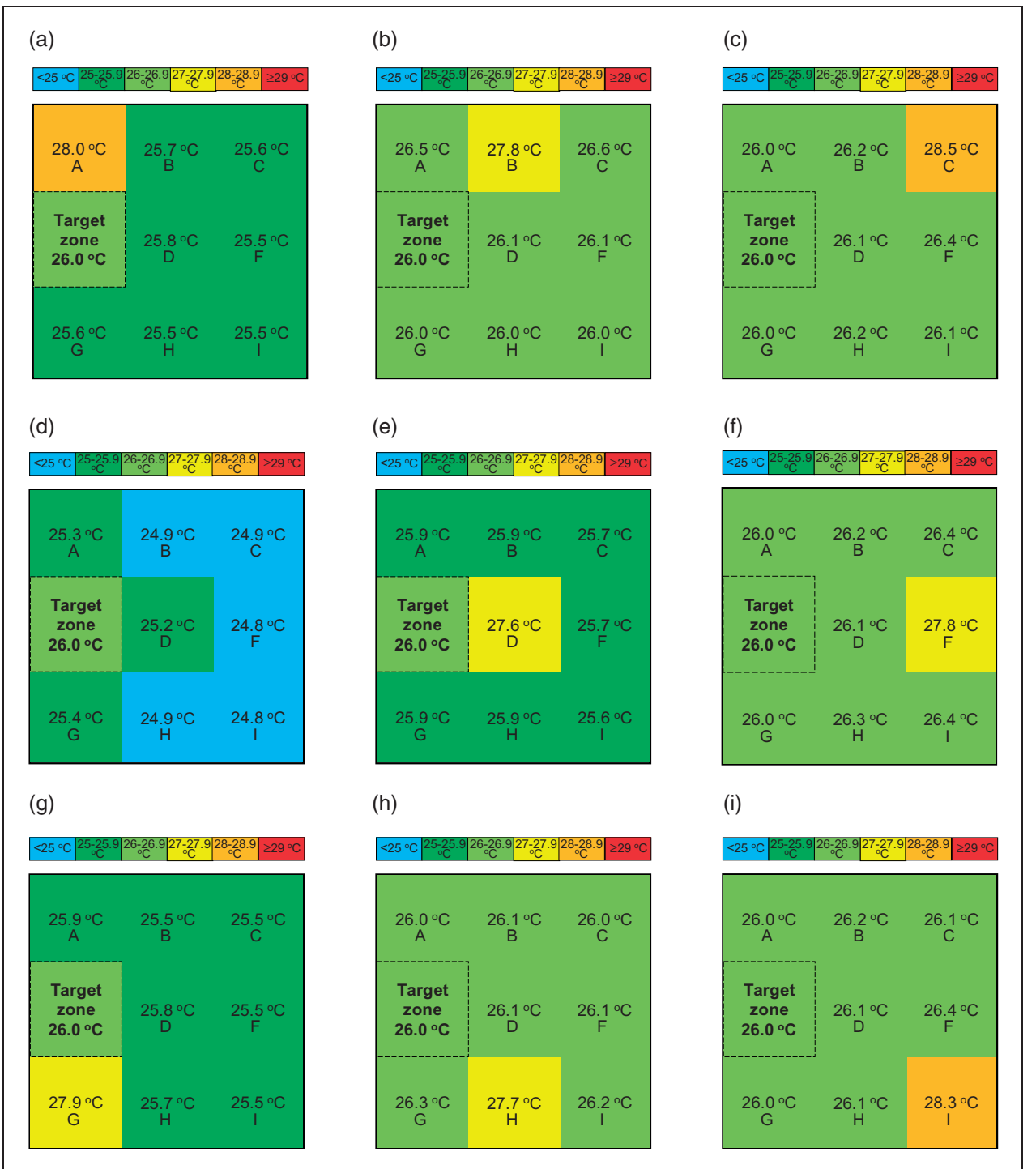

Figure 8. Horizontal air temperature distributions at the height of $0.6 \mathrm{~m}$ in Cases L-1 to L-9. (a) Case L-1, (b) Case L-2, (c) Case L-3, (d) Case L-4, (e) Case L-5, (f) Case L-6, (g) Case L-7, (h) Case L-8 and (i) Case L-9.

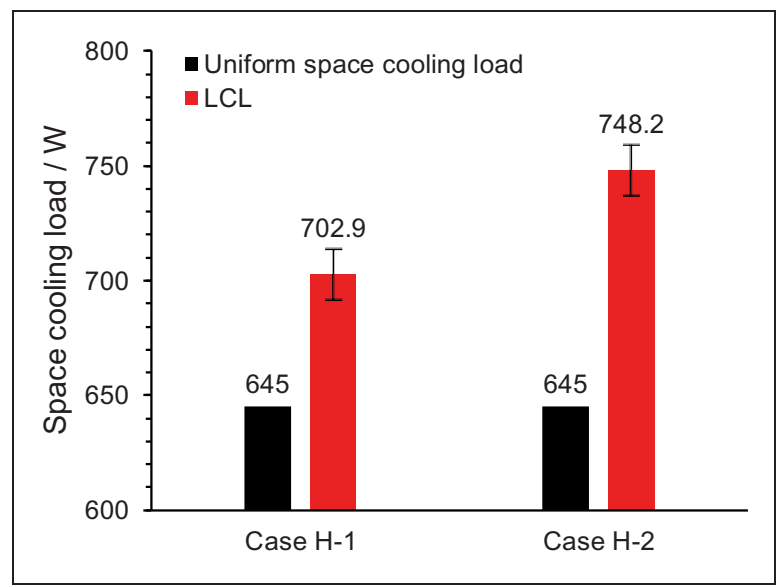

Figure 9. Influence of the shape of heat sources on LCL. LCL: local cooling load.
This means that more heat dissipation of the oil-filled radiator is distributed to the inner surfaces of the envelope, which are far away from the target zone. Therefore, the oil-filled radiator has a smaller influence on the air temperature of the target zone, resulting in a lower LCL.

The horizontal temperature distributions at the height of $0.6 \mathrm{~m}$ in Cases $\mathrm{H}-1$ and $\mathrm{H}-2$ are shown in Figure 10.

From Figure 10, the air temperatures of nine local zones in Case $\mathrm{H}-1$ with the oil-filled radiator were higher than those in Case $\mathrm{H}-2$ with the five metal barrels. Therefore, the heat loss from the envelope was greater, and lower cooling capacity was provided into the room in Case $\mathrm{H}-1$, resulting in a lower LCL (shown in Figure 9). 


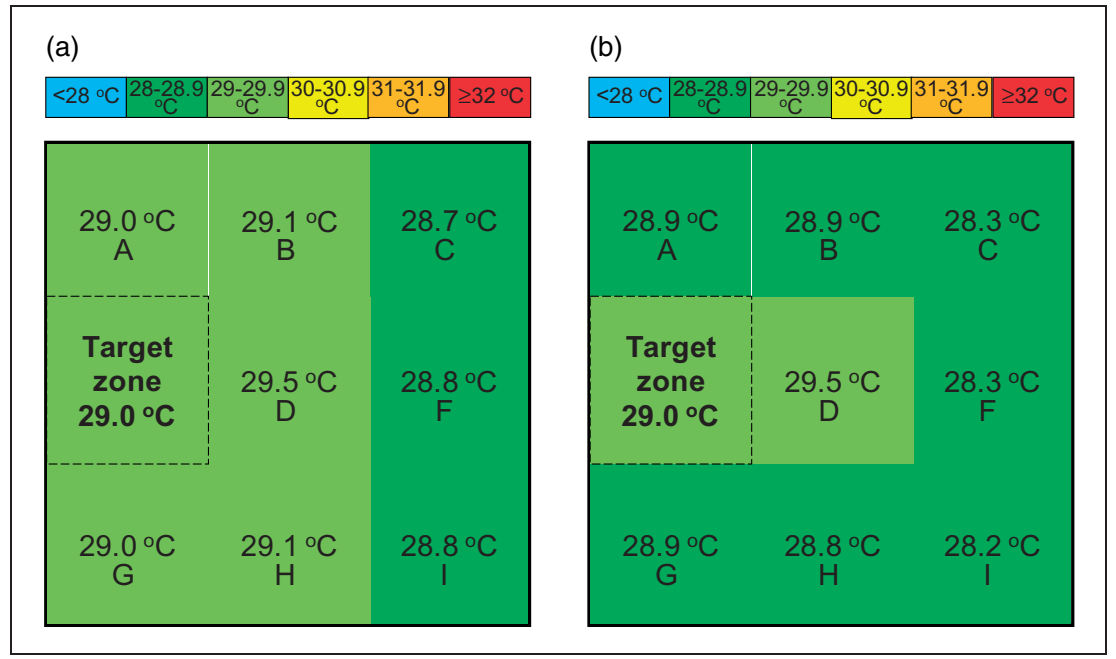

Figure 10. Horizontal temperature distributions at the height of $0.6 \mathrm{~m}$ in (a) Case $\mathrm{H}-1$ and (b) case $\mathrm{H}-2$.

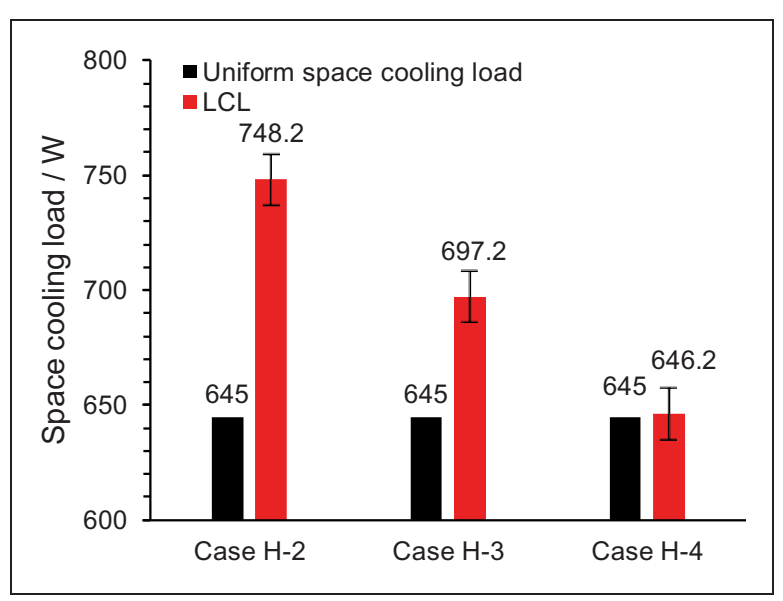

Figure 11. LCL difference between the localized and distributed heat sources.

LCL: local cooling load.

\section{LCL difference between the localized and distributed heat sources}

By comparing Cases H-2, H-3 and H-4, the LCL difference between the localized and distributed heat sources was analysed, and the results are shown in Figure 11.

To describe the degree of concentration of heat sources quantitatively, the non-uniformity coefficient of heat sources is employed here, which is defined as the ratio of the root mean square deviation of heat dissipation in nine zones to the average heat dissipation in nine zones, as equation (3)

$$
k=\frac{\sigma_{q}}{\bar{q}}=\frac{\sqrt{\frac{\sum\left(q_{i}-\bar{q}\right)^{2}}{n}}}{\bar{q}}
$$

where $k$ is the non-uniformity coefficient of heat sources; $\sigma_{q}$ is the root mean square deviation of the heat dissipation of the heat sources in nine zones, $\mathrm{W}$; $\bar{q}$ is the average heat dissipation of the heat sources in nine zones, $\mathrm{W} ; q_{i}$ is the heat dissipation in each local zone, $\mathrm{W} ; n$ is the number of the local zones. The non-uniformity coefficient is smaller, and the heat source distribution is more uniform. According to equation (3), the non-uniformity coefficients of heat sources in Cases $\mathrm{H}-2, \mathrm{H}-3$ and $\mathrm{H}-4$ are 2.8, 1.5 and 0.9 , respectively. In Figure 11, the LCL is the highest at $748.2 \mathrm{~W} \pm 11.2 \mathrm{~W}$ in Case $\mathrm{H}-2$, intermediate at $697.2 \mathrm{~W} \pm 11.2 \mathrm{~W}$ in Case $\mathrm{H}-3$ and the lowest at $646.2 \mathrm{~W} \pm 11.2 \mathrm{~W}$ in Case H-4. This indicates that the LCL would decrease with a decrease in the non-uniformity coefficient of heat sources. Specially, the LCL is very close to the uniform space cooling load in Case $\mathrm{H}-4$, with a small difference of $0.2 \%$. This indicates that the indoor environment would be uniform and the LCL would be equal to the uniform space cooling load (i.e. the total amount of heat sources) in a room with $\mathrm{MV}$, only if the heat sources are also distributed uniformly.

Figure 12 shows the horizontal indoor temperature distributions in Cases H-2, H-3 and H-4. Owing to space constraints, only the distributions at a height of $0.6 \mathrm{~m}$ are shown.

From Figure 12, the indoor air temperature gradually increases with a decrease in the degree of concentration of the five metal barrels, which further proves the highest LCL in Case $\mathrm{H}-2$, intermediate LCL in Case H-3 and the lowest LCL in Case H-4. Specially, the air temperature in each local zone is close to $29^{\circ} \mathrm{C}$ in Case H-4. Therefore, the indoor environment is nearly uniform in Case $\mathrm{H}-4$ with the MV and uniform 
(a)

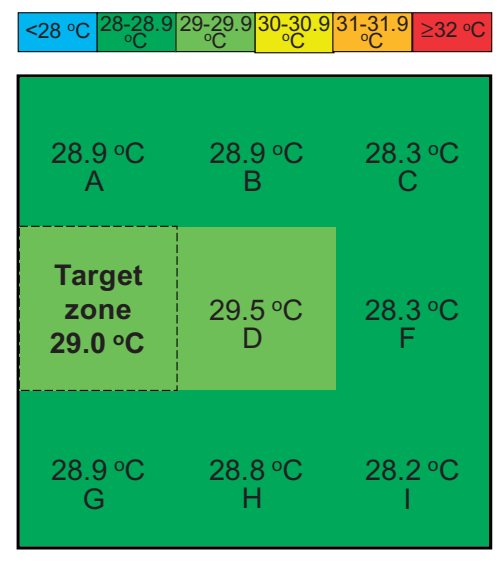

(b)

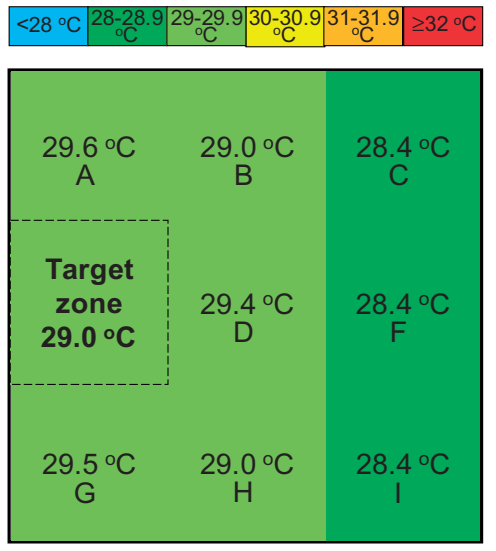

(c)

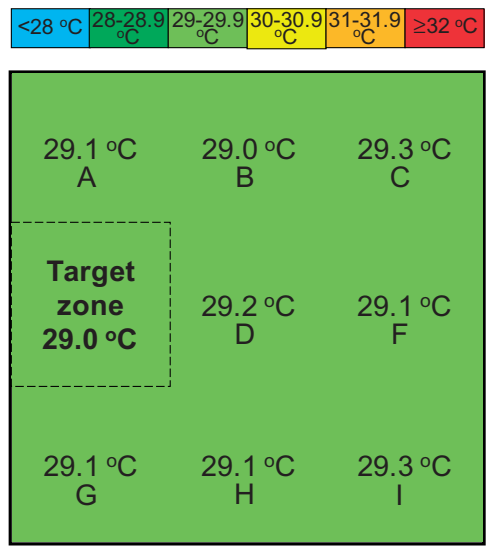

Figure 12. Horizontal temperature distributions at the height of $0.6 \mathrm{~m}$ in (a) cases H-2, (b) case H-3 and (c) and case H-4.

heat source distribution, and the LCL is close to the uniform space cooling load.

\section{Conclusion}

To analyse the influence of the heat source distribution on the space cooling load oriented to local thermal requirements, an experiment in a test chamber with MV was conducted. In the experiment, the heat sources were simulated by metal barrels and an oil-filled radiator, 13 experimental cases with different intensities, locations, shapes and degrees of concentration of the heat sources were designed, and the LCL was used to evaluate the space cooling load. Based on the experimental results, the following conclusions could be drawn:

1. The indoor thermal environment is uniform, and the LCL is equal to the total amount of heat sources in a room with MV only if the heat sources are distributed uniformly. Otherwise, the indoor environment is non-uniform and the LCL varies according to the different heat source distributions.

2. The LCL decreases with the decrease in the intensity of heat sources. It ranges from $646.2 \mathrm{~W} \pm 11.2 \mathrm{~W}$ to $748.2 \mathrm{~W} \pm 11.2 \mathrm{~W}$ in the experimental cases with high intensity, but only from $218.2 \mathrm{~W} \pm 5.6 \mathrm{~W}$ to $340.1 \mathrm{~W}$ $\pm 5.6 \mathrm{~W}$ in the experimental cases with low intensity, indicating a decrease rate of $47.4 \%-70.8 \%$.

3. The location of heat sources has a significant influence on the LCL. When the heat sources are located near the exhaust diffuser or away from the target zone, the LCL is $9.2 \%-22.3 \%$ lower than the total amount of heat sources in the experiment and vice versa.
4. When the intensity and location of heat sources are the same, the LCL is related to the shape of the heat sources. Owing to a much smaller surface area and higher surface temperature, the LCL in the experimental case with an oil-filled radiator is 7\% lower than that with five metal barrels.

The experimental results in this study can help create an efficient indoor thermal environment oriented to local requirements and to operate efficiently the airconditioning system throughout the year.

\section{Authors' contribution}

Chao Liang conducted the experiment, analysed the data and drafted the article. Arsen Krikor Melikov supervised the experiment design and discussed the experimental results. Xianting Li supervised the investigation, revised the article and provided the funding.

\section{Declaration of conflicting interests}

The authors declared no potential conflicts of interest with respect to the research, authorship, and/or publication of this article.

\section{Funding}

The author(s) disclosed receipt of the following financial support for the research, authorship, and/or publication of this article: This study was supported by the National Natural Science Foundation of China (Grant Nos. 51638010 and 51578306), the China Postdoctoral Science Foundation (Grant No. 2018M641536), the National Postdoctoral Program for Innovative Talents (Grant No. BX20180363) and the Fundamental Research Funds for the Central Universities (Grant No. FRF-TP-18-025A2). 


\section{ORCID iDs}

Chao Liang (iD https://orcid.org/0000-0001-9922-2612

Xianting Li (D) https://orcid.org/0000-0003-3421-9505

\section{References}

1. Li Q, Meng QL, Cai JJ, Yoshino H and Mochida A. Applying support vector machine to predict hourly cooling load in the building. Appl Energy 2009; 86: 2249-2256.

2. Owen MS. 2013 ASHRAE Handbook: Fundamentals (Chapter 18). Nonresidantial cooling and heating load calculation. Atlanta: ASHRAE, 2013, pp. 1-3.

3. Heiselberg P. Room air and contaminant distribution in mixing ventilation. ASHRAE Trans 1996; 102: 332-339.

4. He G, Yang X and Srebric J. Removal of contaminants released from room surfaces by displacement and mixing ventilation: modeling and validation. Indoor Air 2005; 15 : 367-380.

5. Al-Sanea SA, Zedan MF and Al-Harbi MB. Effect of supply Reynolds number and room aspect ratio on flow and ceiling heat-transfer coefficient for mixing ventilation. Int $J$ Therm Sci 2012; 54: 176-187.

6. Bosbach J, Lange S, Dehne T, Lauenroth G, Hesselbach $\mathrm{F}$ and Allzeit M. Alternative ventilation concepts for aircraft cabins. CEAS Aeronaut J 2013; 4: 301-313.

7. Amai $\mathrm{H}$ and Novoselac A. Experimental study on air change effectiveness in mixing ventilation. Build Environ 2016; 109: 101-111.

8. Yang B, Melikov AK, Kabanshi A, Zhang C, Bauman FS, Cao G, Awbi H, Wigö H, Niu J, Cheong KWD, Tham KW, Sandberg M, Nielsen PV, Kosonen R, Yao R, Kato S, Sekhar SC, Schiavon S, Karimipanah T, Li X and Lin Z. A review of advanced air distribution methods - theory, practice, limitations and solutions. Energy Build 2019; 202: 109359.

9. Kobayashi N and Chen QY. Floor-supply displacement ventilation in a small office. Indoor Built Environ 2003; 12: 281-291.

10. Schmeling D and Bosbach J. On the influence of sensible heat release on displacement ventilation in a train compartment. Build Environ 2017; 125: 248-260.

11. Schmeling D and Bosbach J. Influence of shape and heat release of thermal passenger manikins on the performance of displacement ventilation in a train compartment. Indoor Built Environ. Epub ahead of print 18 June 2019. DOI: 10.1177/1420326X19856673

12. Minaei A, Ashjaee M and Goharkhah M. Experimental and numerical study of mixed and natural convection in an enclosure with a discrete heat source and ventilation ports. Heat Transfer Eng 2014; 35: 63-73.

13. Fitzgerald SD and Woods AW. On the transition from displacement to mixing ventilation with a localized heat source. Build Environ 2007; 42: 2210-2217.

14. Wu WF, Wu X, Feng YH and Zhang XX. Simulation of velocity and temperature distributions of displacement ventilation system with single or double heat sources. J Therm Sci 2007; 16: 155-158.
15. Kondrashov A, Sboev I and Dunaev P. Evolution of convective plumes adjacent to localized heat sources of various shapes. Int J Heat Mass Transfer 2016; 103: 298-304.

16. Cheng Y, Niu J and Gao N. Stratified air distribution systems in a large lecture theatre: a numerical method to optimize thermal comfort and maximize energy saving. Energy Build 2012; 55: 515-525.

17. Su YX, Su AL and Wan X. Modeling of buoyancydriven natural ventilation in workshop: optimization of distance between heat source and ground. Appl Mech Mater 2012; 170-173: 2579-2582.

18. Harish R. Effect of heat source aspect ratio on turbulent thermal stratification in a naturally ventilated enclosure. Build Environ 2018; 143: 473-486.

19. Park HJ and Holland D. The effect of location of a convective heat source on displacement ventilation: CFD study. Build Environ 2001; 36: 883-889.

20. Zheng G, Shen C, Melikov A and Li X. Improved performance of displacement ventilation by a pipeembedded window. Build Environ 2019; 147: 1-10.

21. Cheng Y, Yang B, Lin Z, Yang J, Jia J and Du Z. Cooling load calculation methods in spaces with stratified air: a brief review and numerical investigation. Energy Build 2018; 165: 47-55.

22. Ahmed AQ, Gao SA and Kareem AK. A numerical study on the effects of exhaust locations on energy consumption and thermal environment in an office room served by displacement ventilation. Energy Convers Manage 2016; 117: 74-85.

23. Ahmed A and Gao S. Thermal comfort and energy saving evaluation of a combined system in an office room using displacement ventilation. Int $J$ Mech Mechatr Eng 2015; 9: 1101-1106.

24. Loudermilk KJ. Underfloor air distribution solutions for open office applications. ASHRAE Trans 1999; 105: 605-613.

25. Chen Q and Glicksman L. System performance evaluation and design guidelines for displacement ventilation. Atlanta: ASHRAE, 2003.

26. Zhou X, Lian Z and Lan L. Experimental study on a bedside personalized ventilation system for improving sleep comfort and quality. Indoor Built Environ 2014; 23: 313-323.

27. Fan DY, Wang QQ, Zhao L and Liu ML. Status, standards, technologies and existing problems of residential ventilation in China. Indoor Built Environ. Epub ahead of print 12 July 2019. DOI: $10.1177 / 1420326 X 19862604$

28. Fanger PO. Human requirements in future air-conditioned environments. Int J Refrig 2001; 24: 148-153.

29. Chen L and Li Y. Effects of different auditorium forms on ventilation in a football stadium. Indoor Built Environ. Epub ahead of print 10 September 2019. DOI: 10.1177/ 1420326X19873132

30. Flynn MR and Susi P. Local exhaust ventilation for the control of welding fumes in the construction industry - a literature review. Ann Occup Hyg 2012; 56: 764-776. 
31. Wang Y, Huang Y, Zhou Y, Shu Y and Liu J. Experimental study on one-side confined jets from a parallel-flow outlet in a push-pull ventilation system. Indoor Built Environ 2015; 24: 73-86.

32. Zhang T, Li P and Wang S. A personal air distribution system with air terminals embedded in chair armrests on commercial airplanes. Build Environ 2012; 47: 89-99.

33. Oh MS, Ahn JH, Kim DW, Fang DS and Kim Y. Thermal comfort and energy saving in a vehicle compartment using a localized air-conditioning system. Appl Energy 2014; 133: 14-21.

34. Melikov AK. Personalized ventilation. Indoor Air 2004; 14: $157-167$.

35. Xie YX, Fu SC, Wu CL and Chao C. Influence of sinusoidal airflow and airflow distance on human thermal response to a personalized ventilation system. Indoor Built Environ 2018; 27: 317-330.

36. Chau OK, Liu CH and Leung MK. CFD analysis of the performance of a local exhaust ventilation system in a hospital ward. Indoor Built Environ 2006; 15: 257-271.

37. Huang YQ, Wang Y, Liu L, Nielsen PV, Jensen RL and Yan FL. Reduced-scale experimental investigation on ventilation performance of a local exhaust hood in an industrial plant. Build Environ 2015; 85: 94-103.

38. Yang B and Sekhar C. Interaction of dynamic indoor environment with moving person and performance of ceiling mounted personalized ventilation system. Indoor Built Environ 2014; 23: 920-932.

39. Gao R, Wang C, Li A, Yu S and Deng B. A novel targeted personalized ventilation system based on the shooting concept. Build Environ 2018; 135: 269-279.

40. Ahmed AQ and Gao S. Numerical investigation of height impact of local exhaust combined with an office work station on energy saving and indoor environment. Build Environ 2017; 122: 194-205.

41. Ahmed AQ, Gao S and Kareem AK. Energy saving and indoor thermal comfort evaluation using a novel local exhaust ventilation system for office rooms. Appl Therm Eng 2017; 110: 821-834.

42. Liang C, Shao X, Melikov AK and Li X. Cooling load for the design of air terminals in a general non-uniform indoor environment oriented to local requirements. Energy Build 2018; 174: 603-618.

43. Liang C, Li X, Melikov AK, Shao X and Li B. A quantitative relationship between heat gain and local cooling load in a general non-uniform indoor environment. Energy 2019; 182: 412-423.

44. Shen C, Shao X and Li X. Potential of an air curtain system orientated to create non-uniform indoor thermal environment and save energy. Indoor Built Environ 2017; 26: $152-165$.

45. Shao X, Ma X, Li X and Liang C. Fast prediction of non-uniform temperature distribution: a concise expression and reliability analysis. Energy Build 2017; 141: 295-307.
46. Kaye NB and Hunt GR. Heat source modelling and natural ventilation efficiency. Build Environ 2007; 42: 1624-1631.

47. Mustakallio P, Bolashikov Z, Rezgals L, Lipczynska A, Melikov A and Kosonen R. Thermal environment in a simulated double office room with convective and radiant cooling systems. Build Environ 2017; 123: 88-100.

48. Kosonen R, Melikov A, Yordonova B and Bozkhov L. Impact of heat load distribution and strength on airflow pattern in rooms with exposed chilled beams. In: Proceedings of 10th international conference on air distribution in rooms, Helsinki, Finland, June 13-15 2007.

49. Koskela H, Häggblom H, Kosonen R and Ruponen M. Flow pattern and thermal comfort in office environment with active chilled beams. HVAC\&R Res 2012; 18: 723-736.

50. Zhu H, Yu CW and Cao S. Ventilation online monitoring and control system from the perspectives of technology application. Indoor Built Environ. Epub ahead of print 4 October 2019. DOI: 10.1177/1420326X19878586

51. Ren C and Cao S. Development and application of linear ventilation and temperature models for indoor environmental prediction and HVAC systems control. Sustain Cities Soc. Epub ahead of print 1 November 2019. DOI: $10.1016 /$ j.scs.2019.101673

52. Lestinen S, KilpeläInen S, Kosonen R, Jokisalo J, Koskela H, Li A and Cao G. Indoor airflow interactions with symmetrical and asymmetrical heat load distributions under diffuse ceiling ventilation. Sci Technol Built Eng 2019; 25: 716-731.

53. Zhao K, Liu XH and Jiang Y. Application of radiant floor cooling in a large open space building with highintensity solar radiation. Energy Build 2013; 66: 246-257.

54. ISO 7726:2001. Ergonomics of the thermal environmentinstrument for measuring physical quantities. Brussels: European Committee for Standardization, 2001.

55. ISO 7730:2005. Ergonomics of the thermal environmentanalytical determination and interpretation of thermal comfort using calculation of the PMV and PPD indices and local thermal comfort criteria. Geneva, Switzerland: International Organization for Standardization, 2005.

56. EN 15251:2007. Indoor environmental input parameters for design and assessment of energy performance of buildings addressing indoor air quality, thermal environment, lighting and acoustics. Brussels: European Committee for Standardization, 2007.

57. Dalewski M, Melikov AK and Vesely M. Performance of ductless personalized ventilation in conjunction with displacement ventilation: physical environment and human response. Build Environ 2014; 81: 354-364.

58. Liang C, Shao X and Li X. Energy saving potential of heat removal using natural cooling water in the top zone of buildings with large interior spaces. Build Environ 2017; 124: 323-335. 